Crop Breeding and Applied Biotechnology 12: 171-178, 2012

Brazilian Society of Plant Breeding. Printed in Brazil

\title{
ARTICLE
}

\section{In vitro germination and embryogenic competence acquisition of Euterpe edulis Martius immature zygotic embryos}

\author{
Cleber Witt Saldanha ${ }^{1 *}$ and Maisa Pimentel Martins-Corder ${ }^{1}$
}

Received 14 November 2011

Accepted 02 June 2012

\begin{abstract}
This study evaluated different aspects of in vitro germination and embryogenic competence of immature zygotic embryos

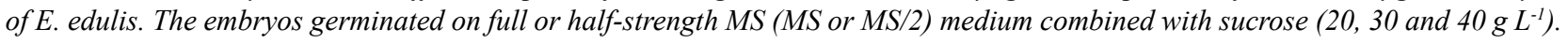
The effect of calcium chloride concentrations $(0,2,4,8$, and $12 \mathrm{mM})$ on the induction of somatic embryogenesis was tested. The embryos were germinated on MS or MS/2. Germination of zygotic embryos and the number of roots per plantlet were not affected by the culture medium and sucrose concentration. Plantlet height and fresh weight were influenced by both; the difference was greatest in MS medium with $40 \mathrm{~g} \mathrm{~L}^{-1}$ sucrose. The induction of somatic embryogenesis was not influenced by doses of calcium chloride, whereas the number of somatic embryos formed was affected. The germination capacity of somatic embryos of heart-of-palm tree was not influenced by the media tested.
\end{abstract}

Key words: Arecaceae, zygotic embryo, micropropagation, morphogenesis, calcium chloride.

\section{INTRODUCTION}

Heart-of-palm tree (Euterpe edulis) has been propagated by seeds only, which lose their germinating power after a few months, preventing long-term storage (Carvalho 2003). Recently, the populations of the species have been depleted by the extraction of palm heart, its main commercial product. However, the species can be exploited for palm heart and fruit pulp production in a sustainable way, intercropped with another palm heart-producing species (Bactris gasipaes) with a shorter cutting cycle than heart-of-palm tree (Cembraneli et al. 2009).

For this purpose, additional strategies must be developed for the preservation of the species and for propagation on a large scale. The in vitro propagation of palms has awakened interest, for facilitating the propagation of elite plantlets on a commercial scale to produce pathogen-free plants and accelerate breeding programs (Ledo et al. 2001). Among the in vitro propagation techniques, the embryo culture and somatic embryogenesis are particularly useful tools in breeding and conservation programs. However, in vitro production of palm trees on a commercial scale is rare.
The embryo culture technique has been widely used as a system for studies related to embryo growth and development (Haslam and Yeung 2011), as well as to assist the exchange and conservation of palm germplasm (Ledo et al. 2007, Engelmann et al. 2011). Embryo culture in plant species has been successfully applied in breeding programs, mainly in the culturing of immature embryos and embryo rescue, since plantlet production by this technique is faster than by the traditional method of seed germination. Some studies have described the in vitro culture of zygotic embryos in palms, Bactris major (Tzec-Simá et al. 2006); Cocos nucifera (Ledo et al. 2001, Fuentes et al. 2005, Ledo et al. 2007), Desmoncus orthacanthos (Tzec-Simá et al. 2006), and Elaeis guineensis (Thawaro and Te-Chato 2010).

Generally, in plantations grown from seeds, the heterogeneity of the seedlings is considerable, which is an undesirable factor for commercial-scale production. For the commercial exploitation of palm trees, methodologies for the selection of elite clones and their large-scale propagation must be developed. Elite genotypes can be directly selected from among plants of natural populations, however, palm species have no axillary meristem, disabling

\footnotetext{
1 Universidade Federal de Santa Maria (UFSM), Departamento de Ciências Florestais, Laboratório de Biotecnologia Florestal, Avenida Roraima, 1000, Bairro Camobi, Santa Maria, 97.105-900, RS, Brasil.*E-mail: clebersaldanha@yahoo.com.br
} 
the conventional techniques of cloning them by vegetative propagation. Somatic embryogenesis may therefore be the only efficient way to propagate palm trees vegetatively on a large scale (Moura et al. 2009). Somatic embryogenesis directly reduces the time required for the micropropagation of plants, minimizing possible genetic alterations that could potentially occur during in vitro culture. Additionally, the process of somatic embryogenesis offers the possibility of propagating a large number of elite genotypes in a short time, and can be applied in synthetic seed production, in mass propagation in bioreactors and in studies of plant genetic transformation (Neumann et al. 2009). Some studies have investigated aspects of in vitro propagation of E. edulis by somatic embryogenesis (Guerra and Handro 1998, Guerra et al. 2000, Saldanha et al. 2006).

The induction and development of somatic embryos depend on several conditions: composition of the culture medium, genotype, explant source, plant hormone type and concentration, proteins secreted into the culture medium, and stress factors (Rose et al. 2010). The influence of nutritional factors of the culture medium on the initiation of embryogenic cultures was analyzed in C. nucifera (Dussert et al. 1995). The induction of somatic embryogenesis in $C$. nucifera was associated with specific substances such as $\mathrm{NH}_{4}^{+}, \mathrm{Ca}^{2+}, \mathrm{Mg}^{2+}$, and sucrose, since nutrient accumulation in the embryogenic cells was high. Among these nutrients, $\mathrm{Ca}$ is considered a second messenger in many hormoneregulated events, playing a key role in several cellular and physiological processes of plants (Das and Pandey 2010). It can stimulate somatic embryogenesis of plant species, playing a role in polarized growth, cell elongation and division and cytoskeletal organization (Arruda et al. 2000, Takeda et al. 2003).

The purpose of this study was to investigate the effect of salt and sucrose concentrations in culture medium on germination and the effect of adding $\mathrm{Ca}$ to the culture medium to induce somatic embryogenesis in immature zygotic embryos of E. edulis, with a view to introduce the technique of in vitro conservation in the medium term.

\section{MATERIAL AND METHODS}

\section{Plant material}

Immature zygotic embryos were extracted from green fruits of E. edulis when the endosperm was still gelatinous, from a natural E. edulis population, in Santa Cruz do Sul, RS, (lat $29^{\circ} 41^{\prime} 1$ ' S, long $52^{\circ} 26^{\prime} 46^{\prime}$ W). After disinfection with tap water and neutral detergent, the fruits were immersed for $15 \mathrm{~min}$ in a solution composed of $1.5 \mathrm{~g} \mathrm{~L}^{-1}$
Agrimycin, sodium hypochlorite (20\%, v/v), $4 \mathrm{~g} \mathrm{~L}^{-1}$ Captan under constant stirring. Thereafter, the fruits were rinsed four times in sterile distilled water and dried on Petri dishes lined with sterile filter paper discs. Disinfection was performed in a laminar flow chamber.

\section{In vitro germination of zygotic embryos}

The zygotic embryos were extracted and inoculated in test tubes $(25 \times 150 \mathrm{~mm})$ sealed with a rigid polypropylene (PP) lid together with approximately $10 \mathrm{~mL}$ MS-based culture medium (Murashige and Skoog 1962), supplemented with Morel vitamins (Morel and Wetmore 1951) and $1.5 \mathrm{~g} \mathrm{~L}^{-1}$ activated charcoal. The culture medium was adjusted to $\mathrm{pH}$ 5.8 and gelled with $7 \mathrm{~g} \mathrm{~L}^{-1}$ agar powder (Merck ${ }^{\circledR}$, Germany) and then sterilized by autoclaving at $121^{\circ} \mathrm{C}$ and $1.5 \mathrm{~atm}$ for $15 \mathrm{~min}$. The cultures were maintained at $25 \pm 2{ }^{\circ} \mathrm{C}$ under 45 $\mu \mathrm{mol} \mathrm{m} \mathrm{m}^{-2} \mathrm{~s}^{-1}$ irradiance and a photoperiod of $16 \mathrm{~h}$.

The treatments consisted of two mineral salt concentrations of the MS medium (100 and 50\%), respectively, designated MS and MS/2 (with half the original salt concentration), mixed with different sucrose concentrations (20, 30 and $\left.40 \mathrm{~g} \mathrm{~L}^{-1}\right)$.

The cultures were first incubated at $25 \pm 2{ }^{\circ} \mathrm{C}$ in total darkness for 10 days. Subsequently, they were transferred to an incubation chamber at the same temperature, photoperiod of 16 hours and $45 \mu \mathrm{mol} \mathrm{m}^{-2} \mathrm{~s}^{-1}$.

The experiment was arranged in a randomized block design with six replications. Each replication consisted of five test tubes containing one immature embryo each. The percentage of germinated immature zygotic embryos of heart-of-palm tree was evaluated 40 days after inoculation. The number of roots, plantlet height and fresh weight were assessed after 100 days. The results of germination were arcsine-transformed $\sqrt{x}$, the number of roots transformed by $\sqrt{x+0.5}$, and the results subjected to analysis of variance and Tukey's test at a significance level of 5\%.

\section{Induction of somatic embryogenesis}

Under aseptic conditions, the embryos were removed from the green fruit and cultured in glass flasks $(250 \mathrm{~mL})$, sealed with a rigid PP lid, containing approximately $30 \mathrm{~mL}$ MS medium, supplemented with Morel vitamins $30 \mathrm{~g} \mathrm{~L}^{-1}$ sucrose, $7 \mathrm{~g} \mathrm{~L}^{-1}$ agar, $0.5 \mathrm{~g} \mathrm{~L}^{-1}$ glutamine, $3 \mathrm{mg} \mathrm{L}^{-1}$, 2-isopentenyladenine (2iP), $100 \mathrm{mg} \mathrm{L}^{-1}$ 2,4-dichlorophenoxyacetic acid (2,4 -D), $1.5 \mathrm{~g} \mathrm{~L}^{-1}$ activated charcoal, as proposed by Guerra et al. 2000). Different concentrations of calcium chloride $\left(\mathrm{CaCl}_{2} \cdot 2 \mathrm{H}_{2} \mathrm{O}\right)$ were used in the study to check the influence on the formation of new tissues. 
The effect of increasing the original $\mathrm{CaCl}_{2} \cdot 2 \mathrm{H}_{2} \mathrm{O}$ concentration ( $3 \mathrm{mM}$ ) in the MS medium with $0,2,4,8,12 \mathrm{mM}$ was tested during the induction of somatic embryogenesis. The somatic embryos were matured by transferring the embryogenic cultures to the MS medium supplemented with Morel vitamins, $7 \mathrm{~g} \mathrm{~L}^{-1}$ agar, $0.5 \mathrm{~g} \mathrm{~L}^{-1}$ of glutamine, $3 \mathrm{mg}$ $\mathrm{L}^{-1} 2 \mathrm{iP}, 50 \mathrm{mg} \mathrm{L}^{-1}$ 2,4-D and $1.5 \mathrm{~g} \mathrm{~L}^{-1}$ activated charcoal, as modified by Guerra and Handro (1998). The cultures were maintained in an incubation chamber at $25 \pm 2{ }^{\circ} \mathrm{C}$ without light during the induction and maturation phases.

\section{Conversion of embryos into plantlets}

For the conversion of somatic embryos (SE) into plantlets MS or MS/2 culture medium supplemented with Morel vitamins was used with $1.5 \mathrm{~g} \mathrm{~L}^{-1}$ activated charcoal. The SEs were inoculated in test tubes $(25 \times 150 \mathrm{~mm})$ sealed with a rigid PP lid containing approximately $10 \mathrm{~mL} \mathrm{MS}$ culture medium. During germination, the embryos were maintained in an incubation chamber at $25 \pm 2{ }^{\circ} \mathrm{C}$ and 16 hours photoperiod (irradiance $45 \mu \mathrm{mol} \mathrm{m}^{-2} \mathrm{~s}^{-1}$ ).

The experiment of induction of somatic embryogenesis was also arranged in a randomized block design with five treatments, consisting of the addition of different concentrations of $\mathrm{CaCl}_{2} \cdot 2 \mathrm{H}_{2} \mathrm{O}(0,2,4,8,12 \mathrm{mM})$ to the MS medium, in six replications. Each plot consisted of a flask containing four zygotic embryos. The experiment of conversion of somatic embryos was set up in a randomized block design with two treatments (MS and MS/2) and 10 replications. The plot consisted of three test tubes, each containing one somatic embryo.
Sixty days after inoculation, the percentage of induction of embryogenic cultures and somatic embryo induction were evaluated. After 150 days, the somatic embryos induced per flask (plot) were counted. The percentage of somatic embryos converted into plantlets was assessed 60 days after inoculation of somatic embryos in a culture medium for conversion into plantlets (MS and MS/2). No subcultures of the embryoids were made during the period in culture medium to induce somatic embryogenesis (150 days), the maturation of somatic embryos (180 days) and the conversion of somatic embryos (60 days). Plantlets from somatic embryos were transferred to sterile substrate (1:1:1, carbonized rice husk, soil and decomposed sawdust), at 25 $\pm 2{ }^{\circ} \mathrm{C}$ and a photoperiod of 16 hours.

The percentage of embryogenic cultures and conversion of somatic embryos was arcsine-transformed $\sqrt{x}$. The number of somatic embryos was transformed by $\sqrt{x+0.5}$.

\section{RESULTS AND DISCUSSION}

\section{Effect of sucrose concentration on in vitro germination of immature zygotic embryos}

The sucrose and salt concentrations of MS medium evaluated in this study showed no significant differences in the germination of immature zygotic embryos of E. edulis (Table 1). On average, $74 \%$ of the embryos germinated. The germination rate $(80 \%)$ of zygotic embryos was highest on MS/2 enriched with $30 \mathrm{~g} \mathrm{~L}^{-1}$ sucrose and on MS with $40 \mathrm{~g}$ $\mathrm{L}^{-1}$ sucrose, 40 days after inoculation. Ten days after inoculation of zygotic embryos, signs of leaf primordia and root

Table 1. Effect of the different culture media (MS and MS/2) and sucrose concentrations on in vitro germination of immature zygotic embryos (40 days after inoculation) and fresh weight, plantlet height and number of roots (120 days after inoculation) of heart-of-palm tree (Euterpe edulis Mart.) plantlets, $F$ test values, obtained for the blocks of different treatments.

\begin{tabular}{|c|c|c|c|c|c|c|c|c|c|c|c|c|}
\hline \multirow{2}{*}{$\begin{array}{l}\text { Sucrose } \\
\text { concentration } \\
\left(\mathrm{g} \mathrm{L} \mathrm{L}^{-1}\right)\end{array}$} & \multicolumn{2}{|c|}{ Germination (\%) } & \multirow{2}{*}{ Mean } & \multicolumn{2}{|c|}{$\begin{array}{l}\text { Fresh matter } \\
\left(\text { g plantlet }^{-1}\right)\end{array}$} & \multirow{2}{*}{ Mean } & \multicolumn{2}{|c|}{$\begin{array}{c}\text { Height } \\
(\mathbf{m m})\end{array}$} & \multirow{2}{*}{ Mean } & \multicolumn{2}{|c|}{ Number of roots } & \multirow{2}{*}{ Mean } \\
\hline & MS & MS/2 & & MS & $\mathbf{M S} / 2$ & & MS & MS/2 & & MS & $\mathbf{M S} / \mathbf{2}$ & \\
\hline 30 & 76.7 & 80.0 & 78.4 & 0.110 & 0.113 & $0.112 \mathrm{AB}$ & $8.5 \mathrm{aA}$ & $10.2 \mathrm{aA}$ & 9.4 & 1.0 & 0.9 & 1.0 \\
\hline 40 & 80.0 & 70.0 & 75.0 & 0.138 & 0.120 & $0.129 A$ & $11.7 \mathrm{aA}$ & $7.1 \mathrm{bA}$ & 9.4 & 1.2 & 1.2 & 1.2 \\
\hline \multicolumn{5}{|l|}{$F$ value } & \multicolumn{2}{|c|}{ Germination (\%) } & \multicolumn{2}{|c|}{$\begin{array}{c}\text { Fresh matter } \\
\left(\text { g plantlet }^{-1}\right)\end{array}$} & \multicolumn{2}{|c|}{$\underset{(\mathrm{mm})}{\text { Height }}$} & \multicolumn{2}{|c|}{$\begin{array}{c}\text { Number of roots } \\
\text { per plantlet }\end{array}$} \\
\hline \multicolumn{5}{|c|}{$F$ (culture medium) } & \multicolumn{2}{|c|}{0.9546} & \multicolumn{2}{|c|}{1.1434} & \multicolumn{2}{|c|}{0.0015} & \multicolumn{2}{|c|}{0.0736} \\
\hline \multicolumn{4}{|c|}{$F$ (sucrose concentration) } & & \multicolumn{2}{|c|}{0.6578} & \multicolumn{2}{|c|}{$4.3830^{*}$} & \multicolumn{2}{|c|}{0.0023} & \multicolumn{2}{|c|}{1.5378} \\
\hline \multicolumn{4}{|c|}{$F$ (culture medium $\mathrm{x}$ sucrose concentration) } & & \multicolumn{2}{|c|}{0.1363} & \multicolumn{2}{|c|}{0.4542} & \multicolumn{2}{|c|}{$4.9155 *$} & \multicolumn{2}{|c|}{0.2095} \\
\hline
\end{tabular}

${ }^{a}$ Means followed by the same lowercase letter in the rows and by the same capital letter in the column differed by the Tukey test at $5 \%$ probability.* significant at $5 \% .{ }^{1}$ coefficient of variation. 
growth were observed. The plantlets were fully developed after 120 days of inoculation of immature zygotic embryos. The germination of zygotic embryos of Olea europaea did not depend on the presence of a carbon source in the culture medium, suggesting that the energy required for germination would be supplied by the reserve tissues of the embryo (Garcia et al. 2002). However, the accumulation of reserve substances in the embryo of E. edulis seeds is low, since accumulation occurs mainly in the endosperm (Panza et al. 2004). The increase in sucrose concentration in MS medium resulted in a higher germination percentage of immature zygotic embryos of E. edulis (Table 1), indicating a possible effect of sucrose on the induction of maturation of the same.

The fresh weight production of palm plantlets did not differ significantly between the sucrose concentrations. The accumulation of fresh weight was highest $(0.129 \mathrm{~g})$ in the treatment containing $40 \mathrm{~g} \mathrm{~L}^{-1}$ sucrose in the culture medium, despite statistically not different from the treatment with $30 \mathrm{~g} \mathrm{~L}^{-1}$ sucrose $(0.112 \mathrm{~g})$. The plantlet height was not influenced by the salt concentration in the MS culture medium, or the presence of sucrose (Table 1). However, the interaction between the two factors affected height growth; the plantlets reached the greatest average height $(11.7 \mathrm{~mm})$ in MS with $40 \mathrm{~g} \mathrm{~L}^{-1}$ sucrose. Palm plantlets with the greatest average height $(12 \mathrm{~mm})$ grew in MS with $40 \mathrm{~g} \mathrm{~L}^{-1}$ sucrose, while the average height was lower $(7.0 \mathrm{~cm})$ in $\mathrm{MS} / 2$ with $40 \mathrm{~g} \mathrm{~L}^{-1}$ sucrose. In MS medium supplemented with $40 \mathrm{~g} \mathrm{~L}^{-1}$ sucrose the germination percentage, fresh weight, average height and number of roots were highest. The number of roots of the palm plantlets did not differ between treatments after 120 days (Table 1 ).

The accumulation of fresh weight per plant was highest at a concentration of $40 \mathrm{~g} \mathrm{~L}^{-1}$ sucrose, after 120 days in MS medium $(0.138 \mathrm{~g})$ and MS/2 $(0.120 \mathrm{~g})$ (Table 1). Less fresh weight was accumulated in MS medium $(0.101 \mathrm{~g})$ and $\mathrm{MS} / 2$ $(0.086 \mathrm{~g})$ with $20 \mathrm{~g} \mathrm{~L}^{-1}$ sucrose. However, statistical analyses showed no differences between the treatments. In this study, the experimental coefficient of variation was $25 \%$ for in vitro germination of zygotic embryos, $26 \%$ for fresh weight of plantlets, $32 \%$ for plantlet height and $12 \%$ for the number of roots (Table 1). In comparison, in Euterpe oleracea, the experimental coefficient of variation was lower for in vitro germination of zygotic embryos (14\%) and plantlet height $(18 \%)$ and greater than the number of roots $(18 \%)$ (Ledo et al. 2001). Nevertheless, the coefficients of variation obtained in this study are explained by the genetic variability in the experimental material, since the zygotic embryos were obtained from fruit of open-pollinated heart-of-palm tree.
The increase in fresh weight of palm plantlets was related to the sucrose concentration in the culture medium. The interaction between sucrose and salt concentrations in the culture medium influenced plantlet height significantly (Table 1). The dry weight of 6-month-old C. nucifera plantlets was related to the sucrose concentration in the culture medium; dry matter was highest at a concentration of $90 \mathrm{~g} \mathrm{~L}^{-1}$. A lower sucrose concentration in the culture medium reduced the dry weight of $C$. nucifera plantlets. On the other hand, the maximum plantlet height of $C$. nucifera was obtained with $45 \mathrm{~g} \mathrm{~L}^{-1}$ sucrose in the culture medium (Fuentes et al. 2005). The same authors observed that $C$. nucifera in vitro plantlets were able to grow without sucrose addition, although they did not survive the transference to ex vitro conditions. In plants grown at intermediate sucrose concentration $\left(45 \mathrm{~g} \mathrm{~L}^{-1}\right)$, photosynthetic responses, high survival rate and rapid $e x$ vitro growth were observed. Low sucrose concentrations decreased the photosynthesis of $C$. nucifera, but increased survival, suggesting that both may have contributed to plantlet establishment and growth under field conditions. The levels of organic and inorganic nutrients in in vitro cultivation influenced several metabolic processes of the plants, interfering with growth and differentiation of plant tissues (Maldaner et al. 2006). Sugars act as carbon source and control the gene expression and plant development (Rolland et al. 2002) as well as in the osmotic regulation of the medium (Paiva Neto and Otoni 2003).

The increase in sucrose concentration from $20 \mathrm{~g} \mathrm{~L}^{-1}$ to 40 $\mathrm{g} \mathrm{L}^{-1}$ associated with the MS/2 salt concentration probably decreased the metabolism of the palm plants, resulting in the lowest plantlet height. The low content of Rubisco protein (Ribulose 1,5-bisphosphate carboxylase) in C. nucifera plantlets grown in vitro was attributed to high sucrose concentrations $\left(90 \mathrm{~g} \mathrm{~L}^{-1}\right)$ in the culture medium (Fuentes et al. 2005), which directly affected their photosynthetic capacity. However, increasing the sucrose concentration from $20 \mathrm{~g} \mathrm{~L}^{-1}$ to $40 \mathrm{~g} \mathrm{~L}^{-1}$ in MS resulted in increased plantlet height (Table 1).

In this study, the average number of roots of palm plants (1.0) was not significantly affected by the treatments. No significant differences between treatments (NAA and BAP) in in vitro germination of zygotic embryos of E. oleracea were observed for the number of roots per plant (2.22) (Ledo et al. 2001).

For the development of the palm plantlets, the culture medium (MS or MS/2) had to be supplemented with sucrose. However, no significant differences between the different culture media were observed for the germination of zygotic embryos. Similar results were reported for in vitro 
germination of zygotic embryos of $O$. europaea, where the addition of mannitol or sucrose to the medium was required for plantlet growth (Garcia et al. 2002).

\section{The acquisition of embryogenic competence of immature zygotic embryos of heart-of-palm tree was not affected by calcium}

The induction of somatic embryogenesis in immature zygotic embryos of E. edulis had not been affected significantly $(p<0.05)$ by the addition of $\mathrm{Ca}$ to the culture medium after 60 days. However, significant differences between the concentrations of $\mathrm{CaCl}_{2} \cdot 2 \mathrm{H}_{2} \mathrm{O}(0,2,4,8,12$ $\mathrm{mM}$ ) were observed for the number of somatic embryos after 150 days (Figure 2). The coefficient of experimental variation of embryogenic cultures was $52 \%, 34 \%$ for the number of embryos after 60 days and 21\%.in the second evaluation after 150 days.

The increase in Ca concentration in the culture medium resulted in a decrease in the mean number of somatic embryos grown from 150-day-old palm plantlets (Figure 1). The basic culture medium (MS), supplemented with growth regulators $2 \mathrm{iP}\left(3 \mathrm{mg} \mathrm{L}^{-1}\right)$ and 2,4-D (100 $\left.\mathrm{mg} \mathrm{L}^{-1}\right)$ without extra Ca supplementation induced the greatest proliferation of embryogenic structures.

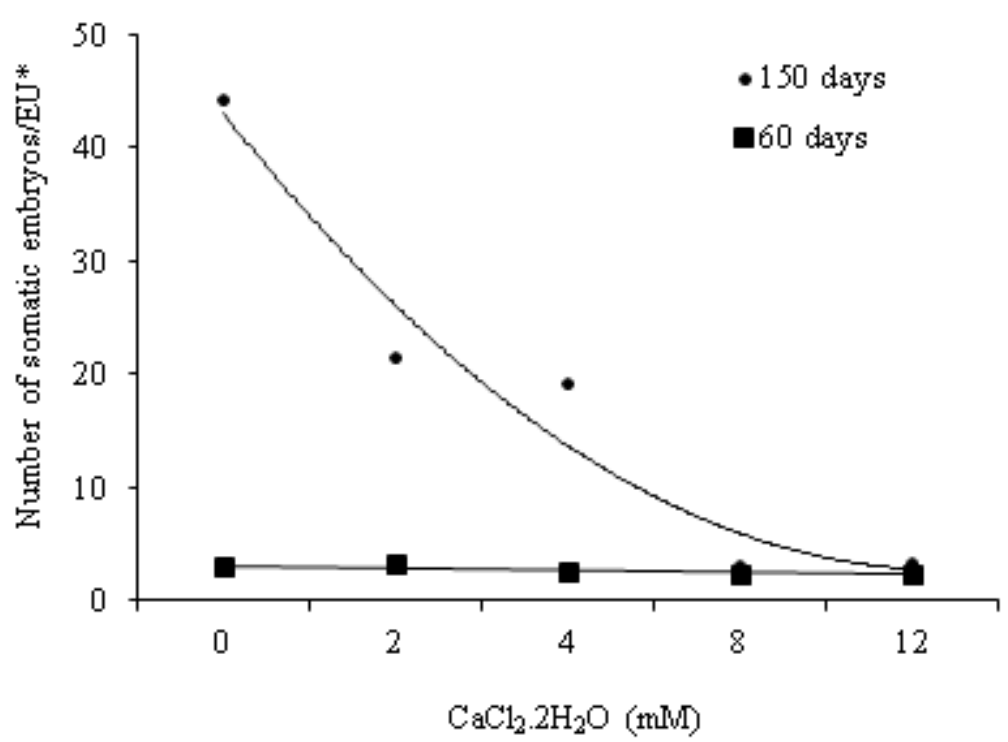

Figure 1. Number of somatic embryos induced from immature zygotic embryos of heart-of-palm tree (Euterpe edulis Mart.) in MS culture medium supplemented with different concentrations of calcium chloride $\left(\mathrm{CaCl}_{2} \cdot 2 \mathrm{H}_{2} \mathrm{O}\right), 60$ and 150 days after inoculation.*Experimental unit. Regression equations: $\mathrm{y}=-0.183 \mathrm{x}+3.35, \mathrm{R}^{2}=0.64(60$ days); $\mathrm{y}=2.306 \mathrm{x}^{2}-23.862 \mathrm{x}+64.514, \mathrm{R}^{2}=0.95$ (150 days). All treatments $(0,2,4,8,12$ $\mathrm{mM}$ of $\left.\mathrm{CaCl}_{2} \cdot 2 \mathrm{H}_{2} \mathrm{O}\right)$ were added to the original $\mathrm{Ca}$ concentration in the MS media.
In this study, we observed the following coefficients of experimental variation: $52 \%$ for embryogenic culture (60 days), $34 \%$ for number of somatic embryos (60 days), $21 \%$ for number of somatic embryos (150 days), and $24 \%$ for germination of somatic embryos. Comparatively, in $B$. gasipaes the coefficient of variation for the percentage of embryogenic cultures was $24 \%$ (Steinmacher et al. 2007a).

The addition of calcium $\left(12 \mathrm{mM} \mathrm{CaCl}_{2}\right)$ to liquid culture medium in cell suspensions of Daucus carota increased the production of somatic embryos (68 embryos $\left.\mathrm{mL}^{-1}\right)$, compared to medium without Ca supplementation $\left(36\right.$ embryos $\left.\mathrm{mL}^{-1}\right)$ after 21 days (Takeda et al. 2003). However, the addition of extra $\mathrm{Ca}$ to the concentration contained in the MS culture medium inhibited somatic embryogenesis in suspension cultures at high concentrations of Daucus carota cells per $\mathrm{mL}$ of suspension. The supplementation of culture medium with $6.12 \mathrm{mM}$ and $6.62 \mathrm{mM} \mathrm{Ca}\left(\right.$ as $\left.\mathrm{CaCl}_{2}\right)$ stimulated the induction of somatic embryogenesis of Eucalyptus urophylla (Arruda et al. 2000). In Hevea brasiliensis, concentrations of $12 \mathrm{mM} \mathrm{CaCl}_{2} \cdot 2 \mathrm{H}_{2} \mathrm{O}$ in the culture medium led to the production of friable calluses, however, the induction of somatic embryos depended on low calcium concentrations (Montoro et al. 1995).

In this study, it was found that the reduction in the auxin concentration of the culture medium for embryo maturation maintained the embryogenic potential of the cultures (Figure 2). Various development stages of somatic embryos were observed, characterizing an asynchronous embryogenetic process (Figure 2C). The transfer of embryogenic cultures containing embryos in the post-globular phase resulted in a progress in the development stage and bipolar maturation (Figure 2D), and subsequently the somatic embryos converted into plantlets (Figure 2E). Similar results were observed in somatic embryogenesis of zygotic embryos of B. gasipaes (Steinmacher et al. 2007a). In a study with E. edulis, after induction of somatic embryogenesis, the embryos were transferred to medium containing $2.5 \mathrm{mg} \mathrm{L}^{-1} 2 \mathrm{iP}$ and 0.1 $\mathrm{mg} \mathrm{L}^{-1} \mathrm{NAA}$ (Guerra and Handro 1998). In this study, the germination of somatic embryos and conversion into plantlets in MS or MS/2 did not differ statistically by the F test, however, in the MS medium, the conversion rate was $50 \%$, and $40 \%$ in $\mathrm{MS} / 2$. The coefficient of variation for germination of somatic embryos was $24 \%$. Guerra and Handro (1998) also had 


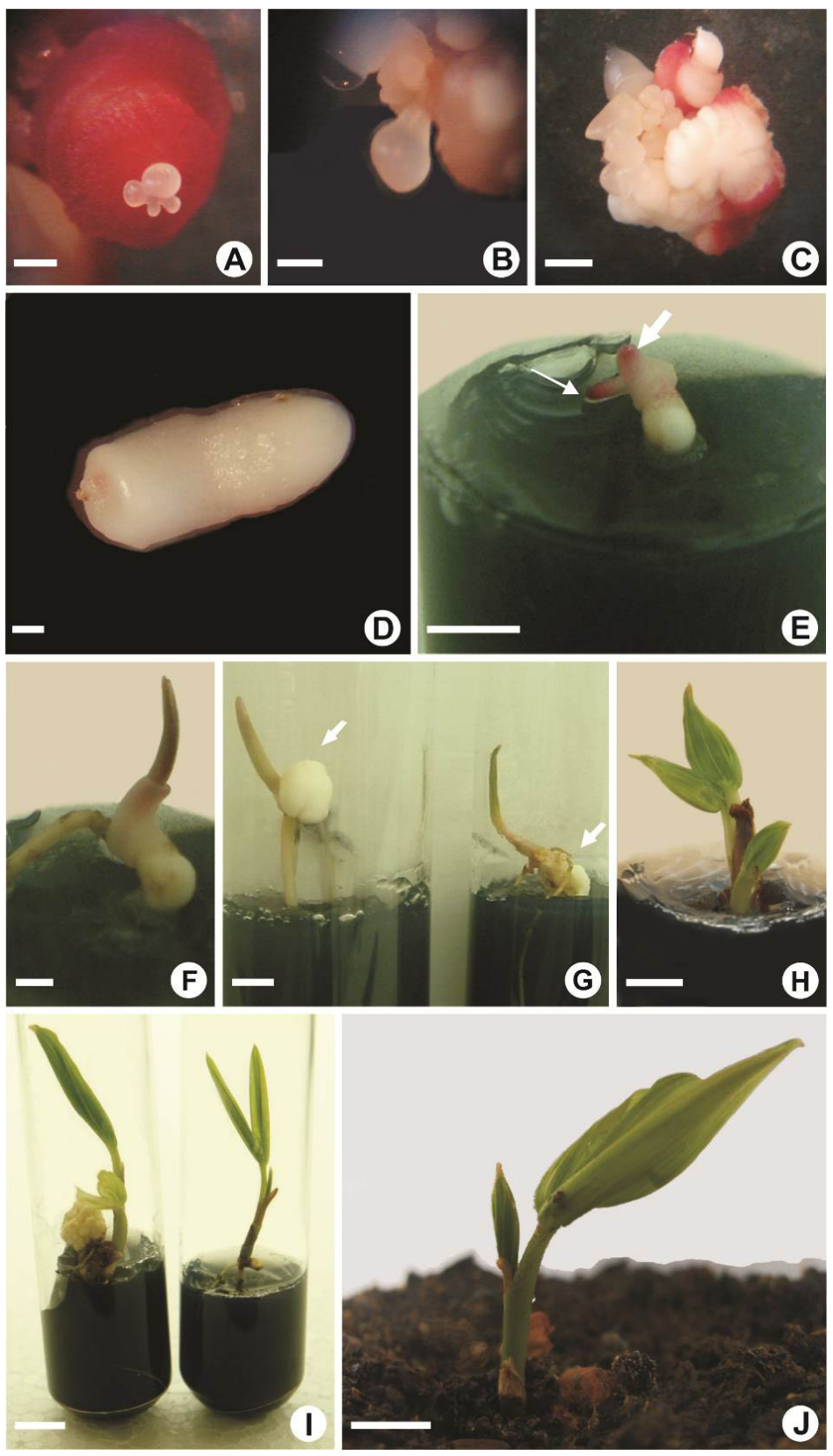

Figure 2. Process of somatic embryogenesis of heart-of-palm tree (Euterpe edulis Mart.). A) Somatic embryos after 140 days of inoculation of immature zygotic embryos in $100 \mathrm{mg} \mathrm{L}^{-1}$ of 2,4-D and $3 \mathrm{mg} \mathrm{L}^{-1}$ of $2 \mathrm{iP}(\mathrm{bar}=0.5 \mathrm{~mm})$. B) Detail of a somatic embryo, after140 days (bar $=0.5 \mathrm{~mm}$ ). C) Somatic embryos in several development stages $($ bar $=1 \mathrm{~mm})$. D) Somatic embryo 10 days after inoculation in MS/2 culture medium (bar $=0.5 \mathrm{~mm}$ ). E) Primordial root (narrow arrow) and plumule (broad arrow), after 20 days $($ bar $=5 \mathrm{~mm})$. F) After 40 days $($ bar $=2 \mathrm{~mm})$. G) Zygotic plantlet on the left and somatic on the right with a haustorium (arrow), after 60 days (bar $=5.0 \mathrm{~mm}$ ). H) Somatic plantlet, after 120 days $(\mathrm{bar}=5 \mathrm{~mm})$. I) Zygotic plantlet on the left and somatic plantlet on the right hand, after 150 days of inoculation of the embryos in $\mathrm{MS} / 2$ culture medium (bar $=10 \mathrm{~mm}$ ). $\mathbf{J}$ ) Acclimatizing somatic plantlet in substrate consisting of carbonized rice husk, soil and decomposed sawdust (1:1:1), after 60 days $($ bar $=10 \mathrm{~mm})$. success with $\mathrm{MS} / 2$ culture medium for conversion of somatic embryos of $E$. edulis on plantlets. The morphogenetic pattern observed during germination of somatic embryos by Handro and Guerra (1998) was similar to that observed in zygotic embryos. The morphology of plantlets from the mature somatic embryos (Figure 2D) was similar to that of germinated zygotic embryos (Figure 2G, 2I), with shoot and root development (Figure 2E, 2F, $2 \mathrm{H}$ ) and plantlets with approximately $5 \mathrm{~cm}$ were obtained 60 days after the beginning of germination of somatic embryos of heart-of-palm tree (Figure 2I). In P. dactylifera, $86 \%$ of the somatic embryos were converted into complete plantlets with $\mathrm{MS} / 2$, containing 0.2 - $0.4 \mathrm{mg} \mathrm{L}^{-1}$ IBA(Al-Khayri 2003).

In vitro germination of zygotic immature embryos of heart-of-palm tree was first reported in this study, showing that the salt-sucrose concentration in the culture medium had no influence on germination. However, growth in plantlet height and fresh weight production depended on the sucrose concentrations. The results of this study indicated the possibility of large-scale propagation of E. edulis palm through somatic embryogenesis. Additional studies related to maturation, the conversion of somatic embryos and the establishment of cell suspension are required to enhance the regeneration protocol. Furthermore, studies would be necessary with other explant sources (leaf sheaths and inflorescence) using thin cell layer explants to induce somatic embryogenesis. This technique is considered promising for somatic embryogenesis of palm species, e.g., for Elaeis guinensis (Scherwinski-Pereira et al. 2010) and B. gasipaes (Steinmacher et al. 2007b). The morphogenetic responses observed in this study were similar to the results reported by Guerra and Handro (1998) and Guerra et al. (2000) in somatic embryogenesis of E. edulis. However, the effect of high Ca levels added to MS medium on the induction of somatic embryogenesis of heart-of-palm tree had not been reported before in the literature.

\section{ACKNOWLEDGEMENTS}

The authors thank Petrobras for the financial support of this work. 


\section{Germinação in vitro e aquisição de competência embriogênica em embriões zigóticos imaturos de Euterpe edulis Martius}

Resumo - Este trabalho avaliou diferentes aspectos da germinação e competência embriogênica in vitro de embriões zigóticos imaturos de palmiteiro. A germinação dos embriões ocorreu em meio MS ou MS/2 combinados com sacarose $\left(20\right.$, 30 e $\left.40 \mathrm{~g} \mathrm{~L}^{-1}\right)$. Para a indução de embriogênese somática foram avaliadas concentrações de Cloreto de cálcio (0, 2, 4, 8 e $12 \mathrm{mM})$. Os embriões somáticos foram germinados em meio MS ou MS/2. A germinação dos embriões zigóticos e o número de raizes por plântulas não foi afetada pela concentração do meio de cultura e de sacarose. A altura e massa fresca das plântulas sofreram influência de ambos, sendo as maiores médias observadas em MS com $40 \mathrm{~g} \mathrm{~L}^{-1}$ de sacarose. A indução de embriogênese somática não apresentou comportamento diferenciado entre doses de Cloreto de cálcio, entretanto, afetou o número de embriões somáticos formados. A capacidade de germinação dos embriões somáticos de palmiteiro não alterou-se nos meios testados.

Palavras-chave: Arecaceae, embrião zigótico, micropropagação, morfogênese, Cloreto de cálcio.

\section{REFERENCES}

Al-Khayri JM (2003) In vitro germination of somatic embryos in date palm: effect of auxin concentration and strength of MS salts. Current Science 5: 680-683.

Arruda SCC, Souza GM, Almeida M and Gonçalves AN (2000) Anatomical and biochemical characterization of the calcium effect on Eucalyptus urophylla callus morphogenesis in vitro. Plant Cell, Tissue and Organ Culture 63: 143-154.

Carvalho PER (2003) Espécies arbóreas brasileiras. Embrapa Florestas, Colombo, 1039p.

Cembraneli F, Fisch STV and Carvalho CP (2009) Exploração sustentável da palmeira Euterpe edulis Mart. no bioma mata atlântica, Vale do Paraíba - SP. Revista Ceres 56: 233-240.

Das R and Pandey GK (2010) Expressional analysis and role of calciumregulated kinases in abiotic stress signaling. Current Genomics 11: 2-13.

Dussert S, Verdeil JL and Buffard-Morel J (1995) Specific nutrient uptake during initiation of somatic embryogenesis in coconut calluses. Plant Science 111: 229-236.

Engelmann F, Malaurie B and N'Nan O (2011) In vitro culture of coconut (Cocos nucifera L.) zygotic embryos. In Thorpe TA and Yeung EC (eds.) Plant embryo culture: methods and protocols. Humana Press, Methods in Molecular Biology, New York, p. 63-72.

Fuentes G, Talavera C, Oropeza C, Desjardins Y and Santamaria JM (2005) Exogenous sucrose can decrease in vitro photosynthesis but improve field survival and growth of coconut (Cocos nucifera $\mathrm{L}$.) in vitro plantlets. In Vitro Cellular and Developmental Biology-Plant 41: 69-76.

Garcia JL, Troncoso J, Sarmiento R and Troncoso A (2002) Influence of carbon source and concentration on the in vitro development of olive zygotic embryos and explants raised from them. Plant Cell, Tissue and Organ Culture 69: 95-100.

Guerra MP, Nodari RO, Peixoto ML and Quinta M (2000) Embriogênese somática e micropropagação do palmiteiro. Sellowia 49-52: 150-162.

Guerra MP and Handro W (1998) Somatic embryogenesis and plant regeneration in different organs of Euterpe edulis Mart. (Palmae): control and structural features. Journal of Plant Research 111: 65-71.
Haslam TM and Yeung EC (2011) Zygotic embryo culture: an overview. In Thorpe TA and Yeung EC (eds.) Plant embryo culture: methods and protocols. Humana Press, Methods in Molecular Biology, New York, p. 3-15.

Ledo AS, Gomes KKP, Barboza SBSC, Vieira GSS, Tupinambá EA and Aragão WM (2007) Cultivo in vitro de embriões zigóticos e aclimatação de plântulas de coqueiro-anão. Pesquisa Agropecuária Brasileira 42: 147-154.

Ledo AS, Lameira OA, Benbadis AK, Menezes IC, Ledo CAS and Oliveira MSP (2001) Cultura in vitro de embriões zigóticos de açaizeiro. Revista Brasileira de Fruticultura 23: 468-472.

Maldaner J, Nicoloso FT, Santos ES, Fagundes CK, Flores R, Jucoski GO and Skrebsky EC (2006) Sacarose e nitrogênio na multiplicação in vitro de Pfaffia glomerata (Spreng.) Pedersen. Ciência Rural 36: 1201-1206.

Montoro P, Etienne H and Carron MP (1995) Effect of calcium on callus friability and somatic embryogenesis in Hevea brasiliensis Müll. Arg.: relations with callus mineral nutrition, nitrogen metabolism and water parameters. Journal of Experimental Botany 46: 255-261.

Morel GM and Wetmore RH (1951) Fern callus tissue culture. American Journal of Botany 38: 141-143.

Moura EF, Motoike SY, Ventrella MC, Sá Júnior AQ and Carvalho M (2009) Somatic embryogenesis in macaw palm (Acrocomia aculeata) from zygotic embryos. Scientia Horticulturae 119: 447-454.

Murashige T and Skoog F (1962) A revised medium for rapid growth and bioassays with tobacco tissue cultures. Physiologia Plantarum 15: 473-497.

Neumann KH, Kumar A and Imani J (2009) Plant propagation-meristem cultures, somatic embryogenesis. In Neumann KH, Kumar A and Imani $\mathrm{J}$ (eds.) Plant cell and tissue culture - a tool in biotechnology: basics and application. Springer-Verlag, Heidelberg, p. 75-135.

Paiva Neto VBP and Otoni WC (2003) Carbon sources and their osmotic potential in plant tissue culture: does it matter? Scientia Horticulturae 97: 193-202. 
In vitro germination and embryogenic competence acquisition of Euterpe edulis Martius immature zygotic embryos

Panza V, Láinez V and Maldonado S (2004) Seed structure and histochemistry in the palm Euterpe edulis. Botanical Journal of the Linnean Society 145: 445-453.

Rolland F, Moore B and Sheen J (2002) Sugar sensing and signaling in plants. The Plant Cell 14: 185-205.

Rose RJ, Mantiri FR, Kurdyukov S, Chen SK, Wang XD, Nolan KE and Sheahan MB (2010) Developmental biology of somatic embryogenesis. In Pua EC and Davey MR (eds.) Plant developmental biologybiotechnological perspectives. Springer-Verlag, Heidelberg, v.2, p. 3-26.

Saldanha CW, Martins-Corder MP, Steinmacher DA and Guerra MP (2006) In vitro morphogenesis in zygotic embryos and leaf sheaths of Euterpe edulis Martius (Arecaceae). Crop Breeding and Applied Biotechnology 6: 228-235.

Scherwinski-Pereira EJ, Guedes RS, Fermino Jr PCP, Silva TL and Costa FHS (2010) Somatic embryogenesis and plant regeneration in oil palm using the thin cell layer technique. In Vitro Cellular and Developmental Biology-Plant 46: 378-385.
Steinmacher DA, Cangahuala-Inocente GC, Clement CR and Guerra MP (2007a) Somatic embryogenesis from peach palm zygotic embryos. In Vitro Cellular and Developmental Biology-Plant 43: 124-132.

Steinmacher DA, Krohn NG, Dantas ACM, Stefenon VM, Clement CR and Guerra MP (2007b) Somatic embryogenesis in peach palm using the thin cell layer technique: induction, morpho-histological aspects and AFLP analysis of somaclonal variation. Annals of Botany 100: 699-709.

Takeda T, Inose H and Matsuoka H (2003) Stimulation of somatic embryogenesis in carrot cells by the addition of calcium. Biochemical Engineering Journal 14: 143-148.

Thawaro S and Te-Chato S (2010) Effect of culture medium and genotype on germination of hybrid oil palm zygotic embryos. ScienceAsia 36: 26-32.

Tzec-Simá MA, Orellana R and Robert ML (2006) In vitro rescue of isolated embryos of Bactris major Jacq. and Desmoncus orthacanthos Mart., potentially useful native palms from the Yucatan Peninsula (Mexico). In Vitro Cellular and Developmental Biology-Plant 42: 54-58. 